\title{
MODERNISASI PERTANIAN (STUDI KASUS TENTANG PELUANG KERJA DAN PENDAPATAN PETANI DALAM SISTEM PERTANIAN DI DESA DUKUHDEMPOK KECAMATAN WULUHAN KABUPATEN JEMBER)
}

\author{
Bayu Enggal Rifkian ${ }^{1}$, Pudjo Suharso ${ }^{1}$, Sukidin ${ }^{1}$ \\ ${ }^{1}$ Program Studi Pendidikan Ekonomi, Fakultas Keguruan dan Ilmu Pendidikan, Universitas Jember
}

\begin{abstract}
The modernization of agriculture is a fundamental change in the patterns of agriculture, from traditional ways to more advanced ways. Including farmers in Village Dukuhdempok, Wuluhan, District Jember, the changes include several things, among others in the processing of soil, the use of superior seeds, the use of fertilizers, the use of agricultural facilities, and the timing of harvesting. The purpose of this study is to determine the impact of agricultural modernization on employment opportunities and income of farmers in the Village Dukuhdempok, Wuluhan, District Jember. The type of this research is descriptive research with qualitative approach. Place of study was determined by using Purposive method. Informant research was determined using snowball method. Data collection techniques in this study using the method of observation, interviews and documents. Data analysis by means of data reduction, data presentation, and conclusion. The results showed that the modernization of agriculture in the village of Dukuhdempok a change in the pattern of traditional community life into a modern society, especially related to technology and agricultural organizations. Farmers in the village of Dukuhdempok indeed undergo many changes in line with technological developments in the field of agriculture that is the change of the guise system into a kolen system, the selection of superior seeds that used to use their own seeds without taking into account the quality of the results and the time taken until the harvest and now have selected superior seeds Which will get more crops and planting time to harvest faster. The existence of modern machines in the field of agriculture by shifting traditional tools such as traditional plows, manual pest eradication tank and also the harvesting process that initially uses ani-ani, then changed to jagrak by pounding the rice stalk and then expand again to the dores Such as a bike, then dores with a diesel engine and is now using a kombin that saves more power and time. From the development of agricultural technology has an impact on the increase in income to the owner farmers and the increased employment opportunities for skilled or skilled hodge.
\end{abstract}

Keywords: The modernization of agricultural, landowners, hodge

\section{PENDAHULUAN}

Sektor pertanian sangat berperan dalam penyerapan tenaga kerja di pedesaan. Sehingga sebagian besar masyarakat pedesaan bekerja di sektor pertanian. Pertanian merupakan salah satu bentuk usaha yang dilakukan oleh masyarakat, terutama masyarakat pedesaan dengan memanfatkan sumber daya modal dan sumber daya alam yang ada seperti: tanah dan air. Masyarakat pedesaan yang bekerja di sektor pertanian terbagi dalam beberapa macam status yaitu petani pemilik, buruh tani, petani penyakap (bagi hasil), dan petani penyewa. Sesuai dengan pendapat Soelaeman (2006:132), masyarakat pedesaan ditentukan oleh basis fisik dan sosialnya, seperti ada kolektivitas, petani individu (pemilik), tuan tanah, buruh tani, pemaro, penyewa dan lain-lain.

Dari beberapa macam petani tersebut, penelitian ini hanya memfokuskan pada petani pemilik dan buruh tani, karena dapat diketahui bahwa petani di desa ada yang sebagai petani pemilik lahan, dan petani yang tidak memiliki lahan. Bagi petani pemilik lahan yang luas tidak menggarap sawahnya sendiri dengan alasan tidak mampu jika harus mengarap semua sawahnya sendiri, sehingga dari sebagian sawahnya ada yang digarap oleh orang lain baik dengan sistem bagi hasil atau upah. 
Petani pemilik selalu bekerja sama dengan buruh tani karena keduanya saling membutuhkan. Buruh tani membutuhkan lahan pertanian dari petani pemilik, sedangkan petani pemilik membutuhkan tenaga buruh tani untuk menggarap lahan yang tidak sanggup digarap sendiri. Semakin banyak petani pemilik yang memberikan kepercayan kepada buruh tani untuk menggarap lahan miliknya, maka semakin besar harapan para buruh tani untuk bekerja dan mendapatkan penghasilan.

Seperti halnya pada masyarakat di Desa Dukuhdempok yang berada di Kecamatan Wuluhan, Kabupaten Jember atau lebih tepatnya berada di wilayah Jember bagian selatan. Berdasarkan data yang diperoleh dari kantor desa Dukuhdempok, diketahui luas lahan persawahan di desa Dukuhdempok yaitu 1.461 Ha, dengan jumlah kepala keluarga yang bekerja di sektor pertanian sebanyak $4230 \mathrm{KK}$, terdiri dari $2516 \mathrm{KK}$ petani pemilik dan $1714 \mathrm{KK}$ petani yang tidak memiliki lahan, mereka bekerja menjadi buruh tani.

Dengan adanya modernisasi kini petani di desa Dukuhdempok dalam pengelohan tanah sudah menggunakan mesin (traktor), bibit yang digunkan bibit unggul, cara penanaman dengan menggunakan ukuran (kenco), dalam pembasmian hama menggunakan mesin, pemupukan menggunakan pupuk lengkap, proses panen sudah menggunakan mesin (kombin), sistem perekrutan tenaga kerja dilihat dari hasil kerja, pencarian tenaga kerja langsung pemilik, dan sistem pembagian hasil berupa uang (bayar langsung setelah bekerja).

Modernisasi dapat diartikan sebagai proses perubahan corak kehidupan masyarakat yang tradisional menjadi masyarakat yang modern, terutama berkaitan dengan teknologi dan organisasi sosial. Teori modernisasi dibangun di atas asumsi bahwa perubahan sosial merupakan gerakan searah (linier), progresif, dan berlangsung perlahan-lahan, yang membawa masyarakat dari tahapan yang primitif kepada keadaan yang lebih maju.

Perubahan-perubahan sosial petani akibat dari modernisasi adalah dengan diperkenalkannya mesin-mesin seperti mesin penuai, dan traktor tangan telah menghilangkan mata pencaharian penduduk yang selama ini mendapatkan upah dari menuai. Kemudian pemakaian traktor tangan telah menggantikan tenaga hewan, sehingga sebagaian besar petani tidak lagi berternak kerbau atau sapi (Scott, 2000 : 202). Menunjukkan bahwa penggunaan teknologi pertanian mempunyai dampak terhadap perubahan struktur masyarakat dan akhirnya berpengaruh terhadap pola-pola institusional masyarakat. Tujuan dari pembangunan pertanian itu sendiri pada dasarnya adalah untuk memperkecil struktur kemiskinan.

Modernisasi pertanian merupakan perluasan perekonomian dan pertumbuhan penduduk di atas sumber daya tanah pertanian terbatas, sampai pula membawa teknologi baru yang menghemat lahan dan padat karya, khususnya paket teknologi bibit unggul dan pupuk pabrik kepada petani. Proses itu disertai perubahan dalam kelembagaan di desa, mengenai hak milik lahan dan ikatan kontrak antara petani, buruh tani dan lain pelaku di desa dan kota (Hayami, 1980).

Modernisasi pertanian merupakan perubahan besar pada pola pertanian dari cara-cara yang tradisional menuju cara-cara yang lebih maju atau modern mencakup berbagai aspek yang meliputi, kelembagaan pertanian, teknologi pertanian, pengembangan sumber daya alam (SDA), dan regulasi.

Selain itu tenaga kerja yang dibutuhkan lebih sedikit dibandingkan dengan dulu yang lebih banyak membutuhkan tenaga manusia. Sehingga petani pemilik yang memiliki lahan yang 
luas tidak mampu untuk mengolah lahannya sendiri. Jadi selain memakan waktu yang lama dan membutuhkan tenaga kerja yang banyak, biaya yang dikeluarkan untuk mengolah juga banyak, sedangkan hasil panen yang diperoleh belum tentu lebih banyak dari biaya yang sudah dikeluarkan.

Peluang kerja merupakan hubungan antara angkatan kerja dengan kemampuan penyerapan tenaga kerja. Pertambahan angkatan kerja harus diimbangi investasi yang dapat menciptakan peluang kerja dengan demikian, dapat menyerap pertambahan angkatan kerja.

Peluang kerja atau kesempatan kerja adalah banyaknya orang yang dapat tertampung untuk bekerja (Disnakertrans, 2002). Peluang kerja ini akan menampung semua tenaga kerja yang tersedia apabila lapangan pekerjaan yang tersedia mencukupi atau seimbang dengan banyaknya tenaga kerja yang tersedia.

Bertitik tolak dari kebijakan tersebut maka dalam rangka mengatasi masalah perluasan kesempatan kerja dan mengurangi pengangguran, departemen tenaga kerja dalam UU No. 13 Tahun 2002 tentang Ketenagakerjaan memandang perlu untuk menyusun program yang mampu baik secara langsung maupun tidak langsung dapat mendorong penciptaan lapangan kerja dan mengurangi pengangguran.

Geertz memperkenalakan dasar teknologi pemerataan atau penyebaran kerja sebagai kapasitas besar penyedot tenaga kerja dari budaya padi yang memungkinkan intensifikasi pemakaian tenaga kerja per unit tanah secara berturut-turut tanpa mengakibatkan berkurangnya produktifitas marjinal tenaga kerja secara besar-besaran:

"Penanaman padi disawah, dengan kesanggupannya yang luar biasa untuk menjaga tingkat produktivitas tenaga kerja yang marjinal dengan selalu mengatur tambahan tenaga seorang lagi tanpa benar-benar mengurangi pendaptan per kapita, telah menyerap hampir seluruh tambahan penduduk yang telah dimunculkan oleh campur tangan orang barat, sekurang-kurangnya secara tidak langsung. Proses yang akhirnya memukul diri sendiri inilah yang saya usulkan untuk dinamakan involusi pertanian (Geertz, 1970:80)."

Melalui intensifikasi penanaman padi yang terus menerus meningkat, seperti panen ganda, mencabut rumput-rumputan dengan lebih hati-hati dan pengawasan perairan, diikuti dengan penataan pemerataan kerja yang cermat, pertanian di Jawa menjadi berinvolusi dengan produktivitas tenaga kerja yang konstan, dan orang desa pun melanjutkan kemiskinan bersamanya. Sekalipun ada tekanan penduduk yang tinggi dan komersialisasi yang meningkat, polarisasi komunitas petani ke dalam petani komersial yang besar dan pekerja upahan yang tidak mempunyai tanah, tidak terjadi.

Bagi petani pemilik yang ada di desa Dukuhdempok sistem kerja dulu menggunakan sistem kedok tetapi kini menggunakan tenaga harian atau upah langsung. Karena adanya modernisasi pertanian sehingga alat-alat yang digunakan lebih maju, maka dalam pengolahan yang dulunya memakan waktu yang lama kini dapat cepat selesai.

Menurut Hernanto (1994), besarnya pendapatan yang akan diperoleh dari suatu kegiatan usahatani tergantung dari beberapa faktor yang mempengaruhinya seperti luas lahan, tingkat produksi, identitas pengusaha, pertanaman, dan efisiensi penggunaan tenaga kerja. Dalam melakukan kegiatan usahatani, petani berharap dapat meningkatkan pendapatannya sehingga kebutuhan sehari-hari dapat terpenuhi. Harga dan produktivitas merupakan sumber dari faktor 
ketidakpastian, sehingga bila harga dan produksi berubah maka pendapatan yang diterima petani juga berubah.

Menurut Gustiyana (2003), pendapatan petani dapat dibedakan menjadi dua yaitu pendapatan usaha tani dan pendapatan rumah tangga. Pendapatan merupakan pengurangan dari penerimaan dengan biaya total. Pendapatan rumah tangga yaitu pendapatan yang diperoleh dari kegiatan usahatani ditambah dengan pendapatan yang berasal kegiatan diluar usahatani. Pendapatan usahatani adalah selisih antara pendapatan kotor (output) dan biaya produksi (input) yang dihitung dalam perbulan, pertahun, permusim tanam. Pendapatan luar usahatani adalah pendapatan yang diperoleh dari akibat melakukan kegiatan diluar usaha tani seperti berdagang, mengojek, dan lain-lain.

Dengan adanya modernisasi pertanian di desa Dukuhdempok membawa perubahan pada pendapatan petani karena adanya pembagian bagi hasil yang dulunya pembagian bawon dengan 5:1 kini dengan kemudahan pekerjaan karena adanya mesin-mesin seperti traktor, tangki pembasmi hama bermesin, dan kombin sistem bawon dirubah menjadi sistem upah atau kolen sehingga penghasilan petani pemilik lebih banyak dibanding dengan sistem bawon.

Berdasarkan latar belakang di atas maka peneliti tertarik untuk mengadakan penelitian dengan judul "Modernisasi Pertanian (Studi Kasus Tentang Peluang kerja dan Pendapatan Petani Dalam Sistem Pertanian Di Desa Dukuhdempok Kecamatan Wuluhan Kabupaten Jember)". Berdasarkan rumusan masalah tersebut, penelitian ini bertujuan untuk mengetahui dampak dari modernisasi pertanian pada peluang kerja buruh tani dan pendapatan petani pemilik dalam sistem pertanian di Desa Dukuhdempok Kecamatan Wuluhan Kabupaten Jember.

\section{METODE PENELITIAN}

Metode penentuan lokasi atau tempat penelitian ditentukan dengan metode purposive area yaitu, desa Dukuhdempok Kecamatan Wuluhan Kabupaten Jember. Penentuan informan penelitian ini menggunakan metode snowball. Informan utama dalam penelitian ini adalah buruh tani terampil dan petani pemilik di desa Dukuhdempok. Informan pendukung dalam penelitian ini adalah anggota keluarga dan kelompok tani di desa Dukuhdempok. Metode yang digunakan untuk pengumpulan data terdiri dari: metode observasi yang digunakan untuk memperoleh data atau informasi dengan menggunakan pengamatan yang dilakukan secara langsung dan sistematis mengenai gejala dan fakta yang diteliti dalam waktu dan tempat tertentu untuk mengetahui kegiatan yang terjadi di lokasi penelitian untuk mendapatkan data sekunder yang nantinya menjadi data pendukung dari wawancara. Metode wawancara dilakukan untuk mendapatkan data primer atau data utama yang digunakan dalam penelitian ini yaitu berkaitan dengan dampak modernisasi pertanian pada peluang kerja dan pendapatan petani dalam sistem petanian. Metode dokumen dilakukan untuk mendapatkan data profil Desa Dukuhdempok, foto yang berkaitan dengan modernisasi pertanian tentang peluang kerja dan pendapatan petani di Desa Dukuhdempok Kecamatan Wuluhan Kabupaten Jember.

Analisis data menggunakan analisis data kualitatif yang terdiri dari reduksi data dilakukan dengan mengidentifikasi data yang terkumpul, kemudian memilah-milah data tersebut sesuai dengan fokus penelitian. Penyajian data merupakan upaya penyajian data agar membentuk sekumpulan informasi yang tersusun secara terorganisir, sehingga mempermudah 
memahami tentang apa yang ditemukan dilapangan pada saat penelitian. Data tersebut disajikan dalam bentuk tabel dan teks naratif yang disusun secara sistematis. Penarikan kesimpulan dalam penelitian ini dilakukan dalam bentuk paparan deskriptif tentang modernisasi pertanian tentang peluang kerja dan pendapatan petani dalam sistem pertanian di Desa Dukuhdempok Kecamatan Wuluhan Kabupaten Jember, yang sebelumnya dituliskan dalam rumusan masalah penelitian. Kesimpulan dalam penelitian ini merupakan suatu temuan baru yang sebelumnya belum pernah ada.

\section{HASIL DAN PEMBAHASAN \\ Hasil Penelitian}

Dari hasil observasi, wawancara, dan dokumen maka dapat diperoleh informasi tentang modernisasi pertanian studi kasus peluang kerja dan pendapatan petani dalam sistem pertanian di Desa Dukuhdempok Kecamatan Wuluhan Kabupaten Jember adalah sebagai berikut:

Modernisasi Pertanian

Modernisasi merupakan proses perubahan corak kehidupan masyarakat yang tradisional menjadi masyarakat yang modern terutama berkaitan dengan teknologi dan organisasi pertanian. Perubahan sistem terlihat jelas dari sistem kedok menjadi sistem kolen dan juga penggunaan benih yang akan ditanam dulu di desa Dukuhdempok penggunaan benih seadanya yaitu benih miliknya sendiri tanpa memperhitungkan hasil panen. Kini para petani di desa Dukuhdempok sudah memilih bibit unggul yang tahan hama, hasil panen lebih banyak, dan waktu panen lebih singkat.

Dalam pembasmian hama dulu menggunakan tangki manual yang membutuhkan tenaga dan waktu yang lebih lama, namun sejak adanya modenisasi pertanian dalam bidang teknologi kini menggunakan tangki bermesin yang dapat menyingkat waktu, tenaga dan biaya yang dikeluarkan menjadi berkurang. Proses pengambilan hasil panen juga mengalami perubahan yang jelas dari ani-ani, pohon padi yang dipukul-pukulkan di alat yang terbuat dari bambu, berubah lagi dores yang dikayuh seperti sepeda lalu ke dores mesin dan sekarang dengan mesin kombin yang langsung mendapatkan biji padi yang siap dijemur.

Sistem pertanian banyak mengalami perkembangan. Dengan adanya kelompok tani banyak mengalami kemajuan sistem pertanian. Karena kelompok tani memberikan penyuluhan pada para petani tentang cara memilih bibit unggul yang tahan hama, waktu panen lebih cepat dan hasil yang melimpah. Dan cara pemupukan yang tepat, cara pembasmian hama dan pemanenan.

Dengan adanya kelompok tani membawa kemajuan pertanian di wilayah Dukuhdempok yaitu dalam pepmbelian pupuk tidak harus bingung kemana-mana langsung beli dikelompok tani. Apalagi kelompok tani mendapatkan bantuan alat kombin dari pemerintah.

Kelembagaan yang ikut berperan dalam kemajuan pertanian adalah Penyuluhan Pertanian Lapangan (PPL) yang memberikan informasi-informasi pertanian dan programprogram pemerintah dalam bidang pertanian yang dilalukan oleh petugas PPL dalam pertemuan kelompok tani. Bantuan-bantuan alat pertanian juga harus mengetahui PPL.

Pada proses pemanenan petani di desa Dukuhdempok menggunakan kombin milik kelompok tani, dan petani tersebut membayarnya lebih murah bila dibanding dengan 
kombin milik pribadi atau kontrak tenaga pemanenan pada sekelompok orang yang menawarkan jasa tenaga pada proses pemanenan.

\section{Peluang Kerja Buruh Tani}

Peluang kerja buruh tani yang terjadi di desa Dukuhdempok mengalami perubahan dari waktu ke waktu, seiring dengan perkembangan sistem pertanian yang lebih maju. Perubahan sistem pertanian yang dulu menggunakan sistem kedok kini menggunakan sistem kolen. Dalam sistem kedok tenaga kerja hanya bekerja di tempat-tempat tertentu saja sedangkan dalam sistem kolen tenaga kerja dapat bekerja dengan bebas tergantung dari penemuan kontrak kerja.

Dengan adanya perubahan sistem yang terjadi di desa Dukuhdempok, maka para buruh tani harus mencari alternatif lain tapi masih dalam bidang pertanian karena kemampuan mereka dibidang pertanian seperti menjadi operator traktor, operator dores jagung dan bahkan membeli tangki untuk pembasmian hama.

Selain pada alat-alat pertanian yang mengalami kemajuan, adanya mordenisasi pertanian juga terjadi pada alat transportasi yang digunakan oleh petani untuk membawa atau memindahkan hasil pertanian dari sawah ke rumah petani. Dimulai dari akses jalan yang gunakan sekarang sudah dibuka jalan yang lebar dan baik sehingga mempermudah transportasi masuk ke lahan persawaan.

Selain akses jalan kemajuan teknologi juga nampak pada alat transportasi yang digunakan petani untuk alat angkut yang berkembang dari pegon (pedati) sampai membuat alat sendiri seperti dedet (alat angkut yang terbuat dari diesel) yang digunakan sebagai sarana angkutan hasil panen para petani.

Alat transportasi dedet merupakan ala yang sangat sederhana, bak (tempat yang digunakan untuk menampung barang) terbuat dari kayu yang dimodif sendiri dan mesinnya dari mesin diesel, sangat membantu petani dalam mengangkut hasil panen karena mempercepat waktu dan biaya petani dalam proses pemanenan.

Pendapatan Petani Pemilik

Pendapatan yang diperoleh oleh masing-masing petani pemilik tidak menentu karena tergantung dari banyaknya hasil panen dan dari luas lahan yang digarap. Bahwa perkembangan pertanian di desa Dukuhdempok mengalami perubahan yang nyata baik dari segi sistem pertanian yaitu pengolahan tanah, penggunaan bibit unggul, pembasmian hama, dan juga pengambilan hasil panen yang dulu tergantung dengan tenaga manusia karena semua pekerjaan dilakukan dengan manual dan kini dilakukan dengan mesin yang dapat menyingkat waktu dan biayanya lebih sedikit. Biaya yang dikeluarkan oleh petani pemilik untuk mengolah lahan pertanian cukup besar. Biaya yang mereka keluarkan untuk mengolah lahan setiap satu hektar 4 juta. Biaya tersebut mereka keluarkan untuk membeli pupuk 2 kwintal sampai 2,5 kwintal terdiri dari urea 1 sak 90 ribu, phonska 3 sak 345 ribu, TSP 1 sak 90 ribu, biaya obat-obatan sekitar 1.075 ribu, biaya benih 400 ribu, biaya pengolahan tanah 1 juta, biaya kuli tanam 1 juta.

Pendapatan petani pemilik yang mempunyai lahan satu hektar sebesar Rp 16.000.000 pada setiap masa panen dari hasil penjualan padi, pada masa satu kali panen mendapatkan kurang lebih 6 ton padi, namun harus memberikan bagi hasil kepada pengedok sebesar 1,2 ton dan biaya yang dikeluarkan kira-kira 3 juta. Ditambah lagi bila ada masalah hama yang tidak terduga sehingga menambah pengeluaran biaya, jadi penghasilan bersih 4 ton padi dengan 
sistem kedok. Sedangkan dengan sistem kolen petani pemilik mengeluarkan biaya 4 juta per hektar dengan hasil panen 6 ton padi dipotong biaya kira-kira 1 ton padi sehingga penghasilan bersih 5 ton padi menjadi milik petani pemilik.

\section{Pembahasan}

Masyarakat desa Dukuhdempok yang lebih banyak bermata pencaharian sebagai petani karena sudah dari nenek moyang mereka yang bekerja sebagai petani sehingga mata pencaharian itu langgeng hingga sekarang karena mereka mempunyai lahan baik dari harta warisan maupun pembelian.

Perubahan yang terjadi pada petani di desa Dukuhdempok karena teknologi pertanian yaitu pada sistem kedok menjadi sistem kolen yang membawa perubahan pada buruh tani. Sistem kedok menjadi sistem kolen yang membawa dampak bagi petani pemilik, akan mendapatkan hasil panen lebih banyak dibanding dengan sistem kedok karena petani pemilik tidak mengeluarkan bawon untuk diberikan kepada petani pengedok atau buruh tani. Sedangkan untuk buruh tani pada sistem kolen hanya mendapatkan uang ongkos yang mereka terima dari mereka bekerja tanpa membawa pulang barang seperti padi atau jagung dari hasil bawon seperti dulu pada sistem kedok. Namun peluang kerja buruh tani lebih meningkat karena mereka dapat bekerja ke juragan yang lain apabila buruh tani tersebut mempunyau keterampilan atau skill. Selain itu adanya perkembangan teknologi pertanian seperti membajak sawah yang awalnya menggunakan tenaga hewan kini menggunakan tenaga mesin sehingga pengolahan lahan cepat terselesaikan. Perkembangan teknologi itu memebawa dampak yang baik bagi operator traktor karena akan memdapatkan lapangan pekerjaan lebih banyak sebab mereka bekerja lebih efisien dan efektif. Sedangkan bagi pemilik bajak tradisional akan kehilangan lapangan pekerjaan. Belum lagi adanya tangki pembasmihama yang awalnya manual kini menggunakan mesin. Dalam proses pemanenan sudah banyak mengalami perubahan dari ani-ani, pohon padi yang dipukul-pukulkan ke jagrak (alat dari bambu) lalu ke dores yang dikayuh, kemudian dores dengan tenaga mesin dan sekarang dengan kombin yang membawa dampak pada berkurangnya tenaga kerja pada sektor pemanenan sehingga mengurangi biaya pertanian dan hasil petani pemilik lebih meningkat.

Dengan berkurangnya lahan garapan mereka harus mencari tambahan penghasilan dengan cara menjadi operator traktor, operator dores jagung, dan operator pembasmi hama dengan mesin. Juragan yang membeli alat-alat yang mendukung proses pertanian seperti tangki pembasmi hama bermesin, dores bermesin sehingga penghasilan mereka mencarai tenaga kerja yang memiliki skil atau keterampilan untuk menjalankan alat itu sehingga peluang kerja buruh tani bertambah dan kebutuhan sehari-hari dapat tercukupi, apalagi untuk biaya sekolah anakanak mereka.

Modernisasi pertanian merupakan perluasan perekonomian dan pertumbuhan penduduk di atas sumber daya tanah pertanian terbatas, sampai pula membawa teknologi baru yang menghemat lahan dan padat karya, khususnya paket teknologi bibit unggul dan pupuk pabrik kepada petani. Proses itu disertai perubahan dalam kelembagaan di desa, mengenai hak milik lahan dan ikatan kontrak antara petani, buruh tani dan lain pelaku di desa dan kota (Hayami, 1980). 
Dari perkembangan teknologi pertanian membawa dampak bagi meningkatnya pendapatan pada petani pemilik dan bertambahnya peluang kerja bagi buruh tani yang mempunyai skill atau keterampilan.

Penanaman padi disawah, dengan kesanggupannya yang luar biasa untuk menjaga tingkat produktivitas tenaga kerja yang marjinal dengan selalu mengatur tambahan tenaga seorang lagi tanpa benar-benar mengurangi pendaptan per kapita, telah menyerap hampir seluruh tambahan penduduk yang telah dimunculkan oleh campur tangan orang barat, sekurang-kurangnya secara tidak langsung. Proses yang akhirnya memukul diri sendiri inilah yang saya usulkan untuk dinamakan involusi pertanian (Geertz, 1970:80).

Dengan adanya modernisasi pertanian membawa damapak pada peluang kerja pada buruh tani, terutama dengan adanya alat-alat pertanian bermesin dapat mengurangi jumlah tenaga kerja yang harus bekerja di sawah sehingga tenaga kerja yang tidak dapat mengoperasikan alat-alat mesin tidak dapat lapangan pekerjaan. Mungkin hanya waktu-waktu tertentu misalnya waktu penanaman padi saja mereka mendapatkan upah karena ada pekerjaan untuk mereka.

Namun lain halnya dengan buruh tani yang mempunyai keahlian menjalankan alat-alat pertanian bermesin mereka justru mendapatkan lapangan pekerjaan karena banyak petani yang membutuhkan pekerjaan mereka. Mereka bekerja terkadang tidak mengenal waktu seperti operator traktor dan dores jagung, mereka bekerja dari pagi sampai malam karena mereka berpindah-pindah tempat dari tempat yang satu ke tempat yang lain karena cakupan pekerjaan mereka lebih banyak. Agar cakupan pekerjaan yang mereka sanggupi cepat terselesaikan.

Dengan adanya modernisasi pertanian (perubahan teknologi) dapat merangsang suatu peralihan dari bagi hasil menjadi pengusahaan oleh pemilik atau perubahan dari penyakap menjadi pekerja upah. Perkembangan permesinan usahatani dalam skala besar, dapat merupakan suatu rangsangan yang kuat untuk perubahan ini. Mesin-mesin besar menurunkan biaya pelaksanaan, karena lebih mudah untuk mengawasi seorang pengemudi traktor dibandingkan dengan sejumlah besar tenaga kerja kasar (Lucas, 1979).

Dengan perkembangan adanya mesin traktor, tangki pembasmi hama bermesin, adanya mesin kombin lebih memudahkan petani dalam pengawasan tenaga kerja dan menurunkan biaya pelaksanaan serta waktu pelaksanaan pekerjaan lebih cepat selesai yang menggeser sistem kedok menjadi sistem kolen. Belum lagi perhitungan pembagian hasil seperti bawon harus diambil hasil panennya untuk bawon yang diberikan kepada pengedok yang bila dihitungkan oleh petani pemilik lebih banyak mengeluarkan bawon bila dibanding dengan mengeluarkan upak pekerja harian dan lebih simpel dan tidak rumit dalam pengawasan tenaga kerja yang membawa dampak bahwa hasil pendapatan petani pemilik lebih meningkat dengan sistem kolen. Sedangkan untuk para buruh tani dapat upah setiap kali bekerja sehingga mendapatkan upah yang menjadi masukkan uang untuk belanja keluarganya, namun para buruh tani tidak mendapatkan bawon dari hasil panen yang dapat mereka simpan sebagai persediaan makan keluarga mereka. 


\section{KESIMPULAN DAN SARAN}

\section{Kesimpulan}

Berdasarkan hasil penelitian dan pembahasan dapat ditarik kesimpulan dari penelitian ini bahwa dampak modernisasi pertanian pada peluag kerja dan pendapatan petani di desa Dukuhdempok Kecamatan Wuluhan Kabupaten Jember. Pada petani pemilik penghasilan yang didapat menjadi meningkat dengan adanya pemilihan bibit unggul, pemupukan dengan kombinasi yang tepat, proses pemanenan dengan tenaga mesin sehingga dapat mengurangi biaya dan ongkos tenaga kerja berkurang dan hasil yang didapat lebih banyak tanpa harus dipotong bawon karena adanya pergantian sistem kedok berganti dengan sistem kolen.

Pada buruh tani yang mempunyai skill peluang kerja mereka lebih meningkat karena para petani pemilik lebih banyak membutuhkan jasa mereka untuk memudahkan dan mempercepat pekerjaan petani pemilik dan juga mengurangi biaya yang dikeluarkan, sehingga kubutuhan mereka dapat terpenuhi dan kahidupan para buruh tani dapat lebih sejahtera.

\section{Saran}

Berdasarkan hasil penelitian dan pembahasan hasil penelitian, maka saran untuk petani pemilik dan buruh tani agar tetap menjalin hubungan baik karena keduanya saling membutuhkan. Petani pemilik sebaiknya lebih mengoptimalkan dalam pengolahan lahan pertanian sehingga memperoleh peningkatan hasil panen namun petani pemilik tidak bisa lepas dari buruh tani karena semua pekerjaan dilakukan dengan kolen (upah langsung) semua itu membawa dampak positif bagi buruh tani karena mendapat upah sehingga menambah penghasilan bagi buruh tani yang mempunyai keahlian sebagai operator alat-alat pertanian bermesin.

\section{DAFTAR BACAAN}

Adiwilaga, Anwas. 1992. Ilmu Usaha Tani: Cetakan II. Bandung: Alumni

Arikunto, Suharsimi. 2005. Manajemen Penelitian. Jakarta : PT. Rineka Cipta

Binswanger, Hans P. 1978. The Economics of Tractors in South Asia (New York: Agricultural Development Council; dan Hyderabad, India: International Crops ResearchInstitute for the Semi-Arid Tropics)

Geertz, Clifford. 1970. Agricultural Involution: The Process of Ecological Change in Indonesia. Berkeley and Los Angeles: University of California Press

Gustiyana, H. 2003. Analisis Pendapatan Usahatani Untuk Produk Pertanian. Jakarta : Salemba Empat

Hanafie, R. 2010. Pengantar Ekonomi Pertanian. Yogyakarta : Andi Offset

Hayami, Yujiro dan Masao Kikuchi.1981. Asian Village Economy at the Crossroads An Economic Approach to Instutional Change. University of Tokyo Press

Hernanto. 1994. Ilmu Usahatani. Penebar Swadaya. Jakarta.

Kuswana, D. 2011. Metode Penelitian Sosial. Bandung: CV. Pustaka Setia.

Lucas, Robert, E.B. 1979. "Sharing, Monitoring, and Incentive: Marshallian Misalocation Reassessed," Journal of Political Economy, Vol. 87 (Juni), hlm. 501-521 
Siahaan, Hotman dkk. 2001. Pers yang Gamang Studi Pemberitaan Jajak Pendapat TimorTimur. Jakarta : Institut Studi Arus Informasi

Soelaeman, M. 2006. Ilmu Sosial Dasar "Teori dan Konsep Ilmu Sosial”. Bandung : Refika Aditama

Sony, Sumarsono. 2003. Ekonomi Manajemen Sumber Daya Manusi dan Ketenagakerjaan. Yogyakarta : Graha Ilmu

Undang-undang nomor 13 tahun 2002 tentang Ketenagakerjaan. 